\title{
The use of guar meal in the diet of sheep
}

\author{
Muna M.M. Ahmed', F.M. El Hag ${ }^{2}$ and Manahil M. Awouda ${ }^{3}$
}

\author{
'Institute of Environmental Studies, University of Khartoum \\ P.O. Box 123, Khartoum, Sudan \\ 2Agriculture Research Association El Obeid Station \\ El Obeid, Sudan \\ ${ }^{3}$ Faculty of Animal Production \\ P.O. Box 32, Khartoum, Sudan
}

(Received 11 June 1999; accepted 13 January 2000)

\begin{abstract}
Thirty castrated desert sheep were used in feedlot performance and digestibility trials. Dietary treatment rations were formulated to replace groundnut cake by guar germ in a basal diet containing (\%): sorghum grain, 30; groundnut hulls, 10; wheat bran, 10; molasses, 9 and common salt 1. Guar germ was included at different percentages: 0-ration A, 10-ration B, 20-ration C, 30-ration D and 40-ration E. Dry matter intake ( $\mathrm{g} / \mathrm{kg} \mathrm{BW})$ was significantly increased at inclusion of guar at levels of 20 or $30 \%$, but significantly depressed at other levels. Digestibility of organic matter and crude protein was significantly improved by inclusion of guar at any level. That of crude fibre, however, was increased only at 30 and $40 \%$ guar levels. Disappearance of dry matter from nylon bags was almost complete within $24 \mathrm{~h}$ for all rations. Body weight gains increased slightly at all levels of guar inclusion in the diet. Except for the 20\% level, the feed conversion ratio was also improved but this was not proved statistically. The best animal performance was obtained in response to including $30 \%$ guar in the diet.
\end{abstract}

KEY WORDS: guar, sheep, nutrition

\section{INTRODUCTION}

The major agro-industrial by-products used as ruminant feed in Sudan are cereal straws, groundnut hulls and haulm, sugar cane tops, sugar cane bagasse, sugar cane molasses, cotton stalks and cotton waste. However, the feeding value of crop residues is commonly limited by their low crude protein, mineral and vitamin contents. Industrial demand for guar gum has increased worldwide over the last thirty years 
resulting in production of increasing amounts of guar meal, which can be used as animal feed. In Sudan, the plant is successfully grown in rainfed savannah regions and exports to the United States reached 100 tones of guar gum in 1997.

Guar meal (GRM) (germ + hulls) is palatable, of higher digestibility and energy utilisation compared with groundnut cake. It has the same crude protein degradability as groundnut cake and can replace up to $30 \%$ of this cake in concentrate rations for small ruminants (Abmandal et at., 1989). GRM constituted up to $50 \%$ of growing buffalo rations without adverse effects on growth and energy utilisation (Patel et al., 1970). However, GRM was shown to decrease true protein degradability in the rumen (Volden and Harstad, 1995).

As guar production is approaching a commercial scale, GRM is expected to replace sorghum and groundnut cake in the diets of both ruminants and monogastrics. The present study was thus initiated to determine the suitable level of guar meal in the diet of sheep as well as to assess its feed conversion ratio.

\section{MATERIAL AND METHODS}

\section{Animals}

Thirty castrated male, 1-1.5-year-old Sudan desert sheep (live body weight $33.25 \pm 5.3 \mathrm{~kg}$ ), divided into 5 groups of 6 animals were used in two experiments: a feeding trial and a digestibility trial.

Feeds

Five rations whose basic ingredients were (\%): sorghum grain, 30; groundnut hulls, 10; wheat bran, 10; molasses, 9 and salt, 1 were prepared. Guar meal was included common at different levels $(0,10,20,30,40 \%)$ replacing groundnut cake (Table 1). The ingredients in each ration were thoroughly mixed before offering it to the animals.

TABLE 1

Composition of the rations, $\%$

\begin{tabular}{lrrrrr}
\hline & \multicolumn{5}{c}{ Ration } \\
\cline { 2 - 6 } Ingredient & $\mathrm{A}$ & $\mathrm{B}$ & $\mathrm{C}$ & $\mathrm{D}$ & $\mathrm{E}$ \\
\hline Sorghum grain & 30 & 30 & 30 & 30 & 30 \\
Guar meal & 0 & 10 & 20 & 30 & 40 \\
Groundnut cake & 40 & 30 & 20 & 10 & 0 \\
Groundnut hulls & 10 & 10 & 10 & 10 & 10 \\
Wheat bran & 10 & 10 & 10 & 10 & 10 \\
Molasses & 9 & 9 & 9 & 9 & 9 \\
Common salt & 1 & 1 & 1 & 1 & 1 \\
\hline
\end{tabular}


Feed intake and body weight measurements

Feeds were offered daily in the morning (08:30). The residues from the previous day were recorded in order to estimate the daily dry matter consumption. Body weight was measured every fortnight for six weeks. The animals had free access to clean water.

\section{Feeding trial}

Animals were randomly allocated to five treatment groups, of six animals. Each group was further subdivided into groups of three animals. The animals in each subgroup were allowed to eat together. The animals were kept in partially shaded enclosures $\left(6 \times 6 \mathrm{~m}^{2}\right)$ fenced with thatch fitted together with wire at a height of $2 \mathrm{~m}$. An adaptation period of 10 days was allowed, followed by an experimental period that lasted for six weeks, during which body weight and feed intake were recorded.

\section{Digestibility trial}

At the end of the feeding trial, three animals were randomly selected from each group, placed in digestibility cages and randomly allocated to the five rations. The animals were fitted with faecal bags and allowed an adaptation period of seven days followed by a measurement period of seven days. The faecal bags were emptied daily and the total amounts of fresh faeces were weighed. A pooled sample of $500 \mathrm{~g}$ of faeces was dried at $65^{\circ} \mathrm{C}$ for $48 \mathrm{~h}$. Proximate chemical analysis was carried out according to AOAC (1980).

\section{Dry matter degradability of the rations}

One fistulated mature steer was used for the measurement of dry matter (DM) degradability of the rations according to Ørskov and McDonald (1979). The steer was kept on ration $\mathrm{C}$ for one month before the commencement of the experiment. Size $6.5 \times 14 \mathrm{~cm}$ nylon bags with pore size $41 \mu \mathrm{m}$ were oven dried at $65^{\circ} \mathrm{C}$ for 30 min and their empty weights were recorded. Five gram samples of each ration were weighed in four repetitions before being placed into the nylon bags. Incubation time was $0,3,6,12,24,36$ and $48 \mathrm{~h}$.

\section{Statistical analysis}

Randomized complete block design was used as a sampling technique, using an analysis of variance procedure (ANOVA) to test the overall significance of the model. Mean separation was examined by Duncan's multiple range test (Thomas et al., 1978) to test the significance between the different groups. 


\section{RESULTS}

Dry matter intake and body weight

The chemical composition of the rations is shown in Table 2. The chemical composition of the rations containing different GRM levels was nearly the same, the crude protein content in ration $\mathrm{E}$ was slightly decreased as no GNC was included in it. Dry matter intake (DMI), body weight and feed conversion ratio (FCR) for sheep fed rations with different guar levels (A, B, C, D and E) are summarized in Table 3. DMI was significantly $(\mathrm{P}<0.05)$ increased by the inclusion of guar meal in the rations. The highest intake was observed with ration $\mathrm{C}$ followed by $\mathrm{D}$, $\mathrm{E}$ and $\mathrm{B}$. On the other hand, body weight gains seemed not to be affected by the different levels of guar in the rations. It should be noted, however, that groups B and D started with significantly lower body weights due to weight loss during the adaptation period in which dry matter consumption was significantly reduced.

TABLE 2

Chemical composition (\% of feed) and metabolisable energy (MJ/kg DM) of the rations on dry matter basis

\begin{tabular}{lccccc}
\hline & \multicolumn{5}{c}{ Rations } \\
\cline { 2 - 6 } Chemical composition & $\mathrm{A}$ & $\mathrm{B}$ & $\mathrm{C}$ & $\mathrm{D}$ & $\mathrm{E}$ \\
\hline Dry matter & 73.7 & 86.7 & 85.0 & 86.5 & 95.9 \\
Organic matter & 66.4 & 80.4 & 77.6 & 79.5 & 78.6 \\
Crude protein & 14.7 & 21.2 & 20.6 & 22.9 & 16.2 \\
Crude fibre & 13.9 & 16.6 & 14.2 & 18.3 & 17.2 \\
Ether extract & 4.4 & 3.5 & 4.6 & 4.0 & 5.6 \\
Ash & 7.3 & 6.2 & 7.4 & 6.9 & 7.3 \\
N-free exiractives & 59.6 & 52.5 & 53.0 & 57.8 & 53.7 \\
*Metabolisable encrgy, MJ/kg DM & 12.18 & 12.18 & 10.66 & 13.01 & 12.06 \\
\hline
\end{tabular}

* calculated according to the equation: $\mathrm{ME}=0.012 \mathrm{CP}+0.013 \mathrm{EE}+0.005 \mathrm{CF}+0.014 \mathrm{NFE}$

\section{Nutrient digestibility}

Nutrient digestibility and total digestible nutrients (TDN) are shown in Table 4. Dry matter, nitrogen-free extractives, and ether extract digestibilities were not affected by GRM levels in the rations. However, organic matter, crude protein and crude fibre digestibilities were significantly $(\mathrm{P}<0.05)$ increased by inclusion of $\mathrm{GRM}$ at all levels. Rations $\mathrm{D}$ and $\mathrm{E}$ showed significantly $(\mathrm{P}<0.05)$ higher crude fibre digestibility compared with the other rations. TDN seemed not to be affected by guar levels in the rations. However, only ration $\mathrm{B}$ showed a significant $(\mathrm{P}<0.05)$ increase in TDN. 
TABLE 3

Effect of different guar meal level in the diet on body weight gain, dry matter intake and feed conversion ( $n=6 ; \pm$ SD)

\begin{tabular}{|c|c|c|c|c|c|c|c|c|c|}
\hline \multirow[b]{3}{*}{ Initial body weight, $\mathrm{kg}$} & \multicolumn{9}{|c|}{ Ration } \\
\hline & \multicolumn{2}{|l|}{ A } & \multicolumn{2}{|l|}{ B } & \multicolumn{2}{|l|}{$\mathrm{C}$} & \multicolumn{2}{|l|}{$\mathrm{D}$} & $\mathrm{E}$ \\
\hline & 35.17 & $3.33^{\mathrm{A}}$ & 31.83 & $\pm 1.75^{\mathrm{B}}$ & $34.92 \pm$ & $3.34^{\mathrm{A}}$ & 30.08 & $2.01^{\mathrm{B}}$ & $34.25 \pm 2.46^{\mathrm{A}}$ \\
\hline Weight gain, g/day & 176.5 & \pm 53.03 & 180.0 & \pm 70.7 & $178.5 \pm$ & \pm 118.1 & 242.2 & \pm 83.44 & $188.7 \pm 58.68$ \\
\hline $\mathrm{g} / \mathrm{kg} \mathrm{BWt}^{0.75}$ & 21.21 & $\pm \quad 5.02$ & 24.78 & \pm 1.63 & $21.82 \pm$ & \pm 10.71 & 33.88 & $\pm \quad 8.59$ & $23.84 \pm 5.17$ \\
\hline Dry matter intake, g/day & 1250 & $\pm 210^{\mathrm{B}}$ & 1050 & $\pm 10^{\mathrm{F}}$ & $1450 \pm$ & $\pm 130^{A}$ & 1200 & $\pm 120^{\mathrm{D}}$ & $1160 \pm 160^{c}$ \\
\hline
\end{tabular}

values are means of six animals \pm SD

A.B.C.D.E $\mathrm{P}<0.01$

TABLE 4

Apparent digestibility coefficients $(\%)$ and total digestible nutrients $(\%)$ in sheep fed different guar levels $(\mathrm{n}=6 ; \pm \mathrm{SD})$

\begin{tabular}{lcrrrr}
\hline & \multicolumn{5}{c}{ Ration } \\
\cline { 2 - 6 } & \multicolumn{1}{c}{$\mathrm{A}$} & $\mathrm{B}$ & $\mathrm{C}$ & $\mathrm{D}$ & $\mathrm{E}$ \\
\hline Dry matter & $71.7 \pm 2.36^{\mathrm{A}}$ & $77.1 \pm 3.78^{\mathrm{A}}$ & $74.9 \pm 4.02^{\mathrm{A}}$ & $77.0 \pm 3.65^{\mathrm{A}}$ & $77.2 \pm 2.95^{\mathrm{A}}$ \\
Organic matter & $69.5 \pm 1.86^{\mathrm{B}}$ & $81.7 \pm 1.76^{\mathrm{A}}$ & $9.9 \pm 2.63^{\mathrm{A}}$ & $82.1 \pm 5.08^{\mathrm{A}}$ & $82.0 \pm 5.48^{\mathrm{A}}$ \\
Crude protein & $78.9 \pm 7.56^{\mathrm{B}}$ & $89.9 \pm 3.1^{\mathrm{A}}$ & $90.4 \pm 1.2^{\mathrm{A}}$ & $91.1 \pm 2.58^{\mathrm{A}}$ & $87.0 \pm 3.05^{\mathrm{A}}$ \\
Crude fibre & $14.2 \pm 7.73^{\mathrm{C}}$ & $9.2 \pm 7.98^{\mathrm{B}}$ & $28.4 \pm 22.72^{\mathrm{A}}$ & $60.7 \pm 7.84^{\mathrm{A}}$ & $64.2 \pm 19.45^{\mathrm{A}}$ \\
N-free extractives & $92.1 \pm 2.3^{\mathrm{A}}$ & $84.9 \pm 6.8^{\mathrm{A}}$ & $95.2 \pm 4.87^{\mathrm{A}}$ & $90.7 \pm 7.8^{\mathrm{A}}$ & $94.5 \pm 7.19^{\mathrm{A}}$ \\
Ether extract & $64.7 \pm 8.63$ & $51.9 \pm 10.2^{\mathrm{A}}$ & $56.9 \pm 10.07^{\mathrm{A}}$ & $52.4 \pm 9.53^{\mathrm{A}}$ & $71.7 \pm 15.05^{\mathrm{A}}$ \\
Total digestible nutrients & $65.5 \pm 0.85^{\mathrm{A}}$ & $57.7 \pm 4.01^{\mathrm{B}}$ & $61.7 \pm 1.84^{\mathrm{AB}}$ & $65.3 \pm 4.39^{\mathrm{A}}$ & $64.8 \pm 2.6^{\mathrm{A}}$ \\
\hline
\end{tabular}

A.B.C $P<0.01$ 
Dry matter degradation

Dry matter degradation of the different rations including guar levels were reflected in DM loss from the nylon bags incubated at different times in the rumen of the fistulated steer. All rations showed a steady increase in DM loss (Table 5a). The most rapid changes were exhibited by rations $\mathrm{D}$ and $\mathrm{E}$. An asymptote was reached at $24 \mathrm{~h}$ incubation time with a gradual increase during hours 36 and 46 . The values for the soluble (a) and insoluble (b) fractions for all rations were nearly the same (Table 5b). Effective degradability (ED) was highest with ration D (30\%) while the other rations' ED were more or less the same.

TABLE 5

(a) Dry matter disapearance from nylon bags

\begin{tabular}{cccccc}
\hline & \multicolumn{5}{c}{ Rations - guar meal, \% } \\
\cline { 2 - 6 } Incubation time & $\mathrm{A}(0)$ & $\mathrm{B}(10)$ & $\mathrm{C}(20)$ & $\mathrm{D}(30)$ & $\mathrm{E}(40)$ \\
\hline 0 & 37.8 & 38.2 & 37.8 & 38.7 & 35.9 \\
3 & 38.4 & 38.5 & 41.2 & 37.7 & 40.8 \\
6 & 44.8 & 46.3 & 43.9 & 50.9 & 43.7 \\
12 & 54.6 & 69.9 & 52.3 & 65.2 & 67.9 \\
24 & 79.9 & 74.0 & 82.3 & 83.8 & 85.2 \\
36 & 87.9 & 86.0 & 89.6 & 89.7 & 89.3 \\
48 & 86.9 & 89.9 & 90.5 & 89.6 & 88.9 \\
\hline
\end{tabular}

(b) Derived constants and effective degradability

\begin{tabular}{lccccc}
\hline & A & B & C & D & E \\
\hline a & 37.8 & 38.2 & 37.8 & 38.7 & 35.9 \\
$\mathrm{~b}$ & 50.1 & 49.7 & 52.7 & 51.0 & 53.4 \\
$\mathrm{a}+\mathrm{b}$ & 87.9 & 87.9 & 90.5 & 89.7 & 89.3 \\
$\mathrm{c}$ & 0.053 & 0.46 & 0.48 & 0.69 & 0.049 \\
ED & 63.63 & 62.05 & 63.62 & 68.28 & 62.36 \\
\hline
\end{tabular}

$a=$ soluble fraction, $b=$ insoluble but fermentable material

$c=$ flow rate constant

$\mathrm{ED}=$ effective degradability

\section{DISCUSSION}

Suppression of dry matter intake at higher GRM levels could be related to its bitter taste and hence unpalatability. Other studies have discussed GRM composition in terms of toxic factors such as trypsin inhibitor (Couch et al., 1966), and various methods of detoxification, e.g. extraction (Tasneem and Subramanian, 1986) 
or autoclaving (Nagra et al., 1985). However, the 20\% GRM level showed a significant increase in DMI suggesting that addition of an equal quantity of groundnut cake in relation to grundnut cake (GNC) might have rendered this ration more palatable.

The significant increase in both organic matter and crude protein digestibility in association with including GRM in the diet of sheep could be related to the high crude protein content in GRM that enhanced the digestibility of these nutrients. Other studies with cattle could not find significant differences in DMI or digestibilities of diets consisting of GNC, guar meal and 3 or $5 \%$ molasses complexbased diets (Chanil and Rathee, 1983). Also goats fed guar cut at pod stage and supplemented with crushed oats showed no significant difference in DMI, nutrient digestibility, and nitrogen balance (Pachauri and Upadhyaya, 1986). The discrepancies obtained in this study compared with others could be related to the different ingredients used with guar. On the other hand, the significant depression in crude fibre digestibility with 0,10 and $20 \%$ GRM could be attributed to the rumen fermentation pattern as influenced by type of ingredients constituting the ration. The percentage proportions of sorghum grain and $\mathrm{GNC}$ were higher than in other rations. These ingredients are known to be highly fermentable resulting in high production of VFA and hence low pH values. According to Mertens (1977), suppression of the cellulolytic bacteria population responsible for $\mathrm{CF}$ digestion occurs at $\mathrm{pH}$ level below 6.7 .

Although the daily weight gain was not significantly changed by the guar level, the highest increase was obtained with the $30 \%$ diet, also FCR was the best with the same ration. Similarly, GRM was found to increase body weight gain equally as groundnut cake (398.5 vs $306.8 \mathrm{~g} /$ day) in calves (Abmandal et al., 1989). Other authors have even used 50\% levels in the diet of buffalo calves (Patel et al., 1970).

We conclude that up to $30 \%$ GRM can be used to replace GNC in the diets for sheep.

\section{REFRENCES}

Abmandat S.S.. Krishna K.G., Vidya S., 1989. Utilization of Cluster bean-meal in rations of growing buffalo calves. Indian J. Anim Sci. 59, 851-854

AOAC, 1980. Association of Official Chemists. Official Methods of Analysis. 13 Edition. Washington, DC

Chanil L., Rathee M., 1983. Urea as feed supplements to improve poor quality roughage. J . Dairy Sci. 39, 162-165

Couch J.R., Creger C.R., Bakshi Y.K., 1966. Trypsin inhibitor in guar meal. Proc. Soc. Exp. Biol. Med. 123, 263-265

Mertens D.R., 1977. Dietary fiber component, relationship to the rate and extent of ruminal digestion. Feed Prod. 36, 187-195 
Nagra S.S., Sthi R.P., Chawla J.S., Chopra A.K., 1985. Nutritive value of enthanol-extracted toasted guar meal for broiler chicks. J. Res. Punjab 22, 742-746

Ørskov E.R., 1992. Protein Nutrition in Ruminants. 2nd Edition. Academic Press, London

Ørskov E.R., McDonald I., 1979. The estimation of protein degradability in the rumen from incubation meaurements weighted according to rate of passage. J. Agr. Sci. 92, 499-503

Pachauri V.C., Upadhayaya R.S., 1986. Nutritive value of Cluster bean (Cyamopsis tetragonoloba) hay as affected by supplementation of oat grain in goats. Indian J. Anim. Sci. 56, 154-155

Patel B.M., Dhanibmand C.S., Shulka P.C., 1970. Nutritive value of guar seed (crushed) and guar meal. Indian Vet. J. 47, 66-70

Sharmal S.V., Bhatia S.K., 1984. Dietary guan meal as a protein supplement for lactating cows. J. Dairy Sci. 37, 409-411

Thomas M., Little F., Jackson H., 1978. Design and Analysis, Agricultural Experimentation. John Willey and Sons, New York

Volden H., Harstad O.M., 1995. Effect of rumen incubation on the true indigestibility of feed protein in the digestive tract determined by nylon bag techniques. Acta Agr. Scand. 45, 106-115

\section{STRESZCZENIE}

\section{Mączka z guaru w żywieniu owiec}

Trzydzieści skopów owcy pustynnej, o średniej masie ciała $33 \mathrm{~kg}$, podzielono na 5 grup po 6 zwierząt. Mączką z guaru zastępowano makuch arachidowy $w$ dawce podstawowej o składzie, \%: ziarno sorgo, 30; łuski arachidowe, 10; otręby pszenne, 10; melasa, 9 i sól pastewna, 1. Udział mączki z guaru w dawkach był następujący, \%: 0, 10,20,30 i 40, odpowiednio w dawkach A, B, C, D i E. Pobranie suchej masy pasz na kg masy ciała zwiększyło się istotnie przy skarmianiu dawek zawierających 20 i $30 \%$ mączki z guaru, a obniżyło się istotnie przy podawaniu pozostałych dawek z guarem. Strawność substancji organicznej i białka ogólnego byla istotnie większa przy skarmianiu wszystkich dawek zawierających mączkę z guaru, natomiast strawność włókna była większa na dawkach zawierających 30 i 40\% mączki z guaru niż w grupie kontrolnej bez udziału tej mączki. Ubytek suchej masy wszystkich skarmianych dawek podczas ich inkubacji w żwaczu in sacco po 24 godzinach był prawie całkowity. Przyrosty masy ciała skopów na wszystkich dawkach zawierających guar były nieco większe niż w grupie kontrolnej, a wykorzystanie paszy było, z wyjątkiem dawki zawierającej $20 \%$ mączki z guaru, nieco lepsze ( $>>0.05)$. Najlepsze wyniki uzyskano u skopów otrzymujących dawkę z $30 \%$ udziałem guaru. 